\title{
BMJ Open Systematic review of pathways for the delivery of allergy services
}

\author{
Lavanya Diwakar, ${ }^{1}$ Carole Cummins, ${ }^{2}$ Richard Lilford, ${ }^{3}$ Tracy Roberts ${ }^{1}$
}

To cite: Diwakar $L$,

Cummins C, Lilford $\mathrm{R}$, et al. Systematic review of pathways for the delivery of allergy services. BMJ Open 2017;7:e012647.

doi:10.1136/bmjopen-2016012647

- Prepublication history and additional material is available. To view please visit the journal (http://dx.doi.org/ 10.1136/bmjopen-2016012647).

Received 16 May 2016 Revised 3 January 2017 Accepted 13 January 2017

CrossMark

${ }^{1}$ Health Economics Unit, University of Birmingham, Birmingham, UK

${ }^{2}$ Institute of Applied Health Research, University of Birmingham, Birmingham, UK

${ }^{3}$ Population Evidence and Technologies Unit, Warwick Medical School, University of Warwick, Coventry, UK

Correspondence to Dr Lavanya Diwakar; I.diwakar@bham.ac.uk

\section{ABSTRACT}

Objectives: The incidence and prevalence of allergies worldwide has been increasing and allergy services globally are unable to keep up with this increase in demand. This systematic review aims to understand the delivery of allergy services worldwide, challenges faced and future directions for service delivery.

Methods: A systematic scoping review of Ovid, EMBASE, HMIC, CINAHL, Cochrane, DARE, NHS EED and INAHTA databases was carried out using predefined inclusion and exclusion criteria. Data on the geographical region, study design and treatment pathways described were collected, and the findings were narratively reported. This review followed the Preferred Reporting Items for Systematic Reviews and Meta-analyses (PRISMA) guidelines.

Results: 205 publications were screened and 27 selected for review. Only 3 were prospective studies, and none included a control group. There were no eligible publications identified from North America, Africa, Australia and most parts of Asia. Most publications relate to allergy services in the UK. In general, allergy services globally appear not to have kept pace with increasing demand. The review suggests that primary care practitioners are not being adequately trained in allergy and that there is a paucity of appropriately trained specialists, especially in paediatric allergy. There appear to be considerable barriers to service improvement, including lack of political will and reluctance to allocate funds from local budgets.

Conclusions: Demand for allergy services appears to have significantly outpaced supply. Primary and secondary care pathways in allergy seem inadequate leading to poor referral practices, delays in patient management and consequently poor outcomes. Improvement of services requires strong public and political engagement. There is a need for well-planned, prospective studies in this area and a few are currently underway. There is no evidence to suggest that any given pathway of service provision is better than another although data from a few long-term, prospective studies look very promising.

\section{INTRODUCTION}

The incidence and prevalence of allergic diseases has been steadily increasing globally. ${ }^{1}$ It is recognised that there has been an increase

\section{Strengths and limitations of this study}

The literature review was carried out using eight major databases and reporting followed the PRISMA guidelines.

- This is comprehensive review of all the published reports and journal articles on allergy services.

- No eligible publications were identified from large geographical areas such as North America, Africa, Australia and most of Asia; most publications were UK based.

- Service pathways for allergy and eczema were considered in the review.

in the prevalence of allergies in children and young adults with each passing decade. ${ }^{2}$ Despite this increasing need, allergy services have not improved worldwide. ${ }^{3}$ It is now well established that developed countries bear a higher burden of allergic disease. ${ }^{1}{ }^{4-6}$ However, services rendered to the affected individuals in these higher income countries remain inadequate with deficiencies in primary and secondary care provision. ${ }^{37}$ The picture is similar across many countries with long waiting times for specialist appointments and wide heterogeneity in provision of primary care and specialist services. ${ }^{7} 8$ In addition, the growing incidence of serious allergic manifestations such as anaphylaxis ${ }^{9-}$ ${ }^{12}$ as well as that of individuals with multiple, complex allergies ${ }^{13}$ has prompted calls for improved services worldwide. ${ }^{3} 13$

The UK has one of the highest rates of allergy and related diseases in the western hemisphere $^{1}$ with a steady increase in the prevalence, severity and complexity of allergic disease in the last two to three decades. $^{2}{ }^{14-17}$ It is estimated that $30 \%$ of all adults and $40 \%$ of children in the UK will be affected by allergy-related conditions. ${ }^{18}$ Nevertheless, allergy services have remained 'woefully poor' 18 with very limited and patchy specialist service availability. This shortfall in service availability and the inherent heterogeneity of limited available services has been the focus of multiple expert body reviews in the UK, which have called for 
increased investment in allergy management and for reorganisation of allergy services. ${ }^{18-22}$

One of the major barriers to service planning in allergy is the lack of political engagement and reluctance to allocate funds from the local budget for improving allergy services. ${ }^{23}{ }^{24}$ Allergy is not generally perceived as a serious condition with major implications for health and quality of life. There is a growing body of evidence to the contrary, however. It is now established that children with food allergies are more anxious than those with insulin-dependent diabetes and tend to have overprotective and very anxious parents. ${ }^{25}$ This is also true of adolescents with a history of anaphylaxis. ${ }^{26}$ In addition, the costs of allergies can be considerable. Allergy and related conditions are estimated to cost the UK NHS about $£ 1$ billion per year. ${ }^{27}$ Productivity losses associated with allergic rhinitis in the USA were higher than those due to stress, migraine and depression. ${ }^{28}$ Studies have shown that effective allergy services can not only improve quality of life, but can also be cost-saving. ${ }^{29}$ 30 Hence, there is an urgent need to impress on policymakers the importance and wisdom of investing in the improvement of allergy services.

There is currently no agreement on how allergy services should be structured. In the UK and Europe, Primary Care Physicians - known as GPs or General Practitioners in the UK - (PCPs) diagnose and manage the majority of individuals with allergies ${ }^{7}$ whereas in Australia and the USA, specialist services provide the bulk of allergy care. ${ }^{8}$ Allergy service delivery by non-clinician practitioners such as pharmacists and dieticians, while possible, is not optimally used. ${ }^{22}$ Various pathways have been suggested and are being tested. ${ }^{23} 3132$ However, it is not yet clear whether any particular model of service delivery may be preferable to the others.

The aim of this systematic review is to assess published approaches to allergy service delivery. The objective is to identify and appraise these publications to gain an understanding of the advantages as well as challenges associated with these service pathways; and also to explore current ideas regarding the future direction for these services.

\section{METHODS}

The Preferred Reporting Items for Systematic Reviews and Meta-analyses (PRISMA) guidelines were followed in conducting this systematic scoping review. The PRISMA checklist is supplied as online supplementary file S1.

\section{Data sources and search strategy}

A systematic search of the literature was carried out to identify articles related to allergy service pathways in humans. Search terms included allergy, eczema, care, service and pathway (see online supplementary file S2). MEDLINE, EMBASE, HMIC, CINAHL, Cochrane, DARE, NHS EED and INAHTA websites were searched for the purposes of this review. Searches included publications indexed until the 4th of October 2016. In order for the MEDLINE searches to be relevant, we stipulated that two papers selected a priori ${ }^{3}{ }^{33}$ should be identified in the search. References within the publications identified as relevant were individually examined to identify more articles of interest. Publications citing the chosen articles were also carefully examined for relevance.

\section{Selection of literature}

After discarding duplicates, the title and abstract of the articles were examined for relevance. Where these were not informative, the full text of the publication was reviewed. Articles were included for review if they discussed pathways for the delivery of allergy or eczema services. Publications which reported opinions, conference abstracts, case reports or case series were excluded. Non-English language articles were not included in the review. Asthma service pathways were also not considered. One of the researchers (LD) carried out the searches with help and advice from an information specialist from the University of Birmingham. LD screened all the articles as per the predetermined criteria. A total of $50 \%$ of the unselected articles $(25 \%$ each) were reviewed independently by two of the coauthors (TR and CC). Disagreements, if any, were resolved through discussion and consensus.

The PRISMA flow chart for selection of articles is shown in figure 1.

\section{Data extraction and analysis}

The data extraction form was piloted initially using a few publications. Appropriate modifications were made before starting the full extraction process.

The data were extracted by LD using extraction table that was previously agreed with the coauthors. Data extraction was scrutinised independently by two other authors (CC and TR).

For each publication, the author, year of publication, geographical region of interest, type of study (report, discussion, consensus, etc), study design (prospective, retrospective, cross section), treatment pathway ( primary, secondary or both), principal findings and key recommendations were extracted.

Most of the articles were descriptive; hence the analysis followed a narrative synthesis. This is common in reviews of very heterogeneous studies which aim to describe and scope the area of interest. ${ }^{34}$ Since the objective of the report was to explore options for service delivery, the review was designed to be inclusive. Publications were, therefore, not excluded based on quality criteria but were described and briefly critiqued as appropriate given the nature of the studies. We aimed to map the current literature and understand the type of evidence available in this area (ie, allergy pathways). 

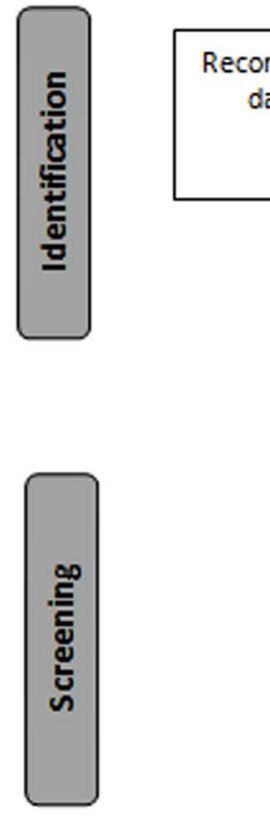

Total number of records considered

ords identified throug database searching

$(n=312)$

Additional records identified through other sources

$(n=12)$

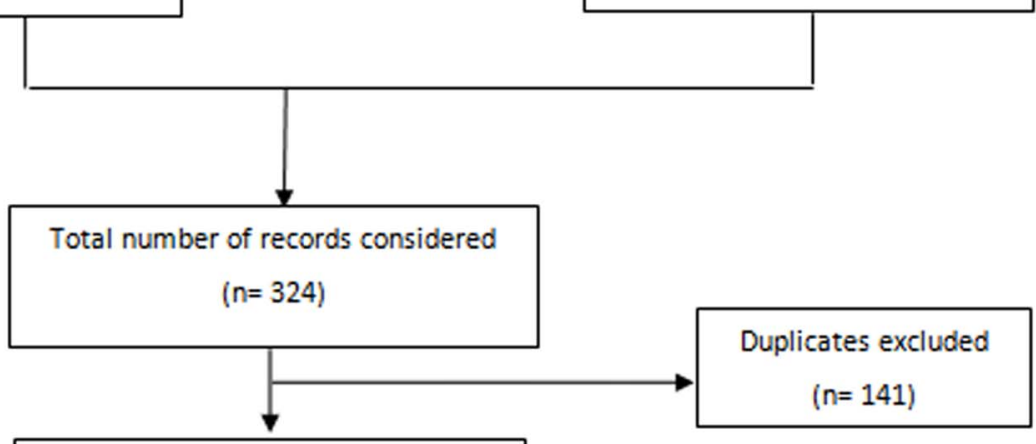

Records screened (title + abstract)

$(n=183)$

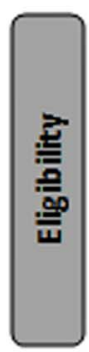

Full text articles assessed for eligibility

$(n=57)$
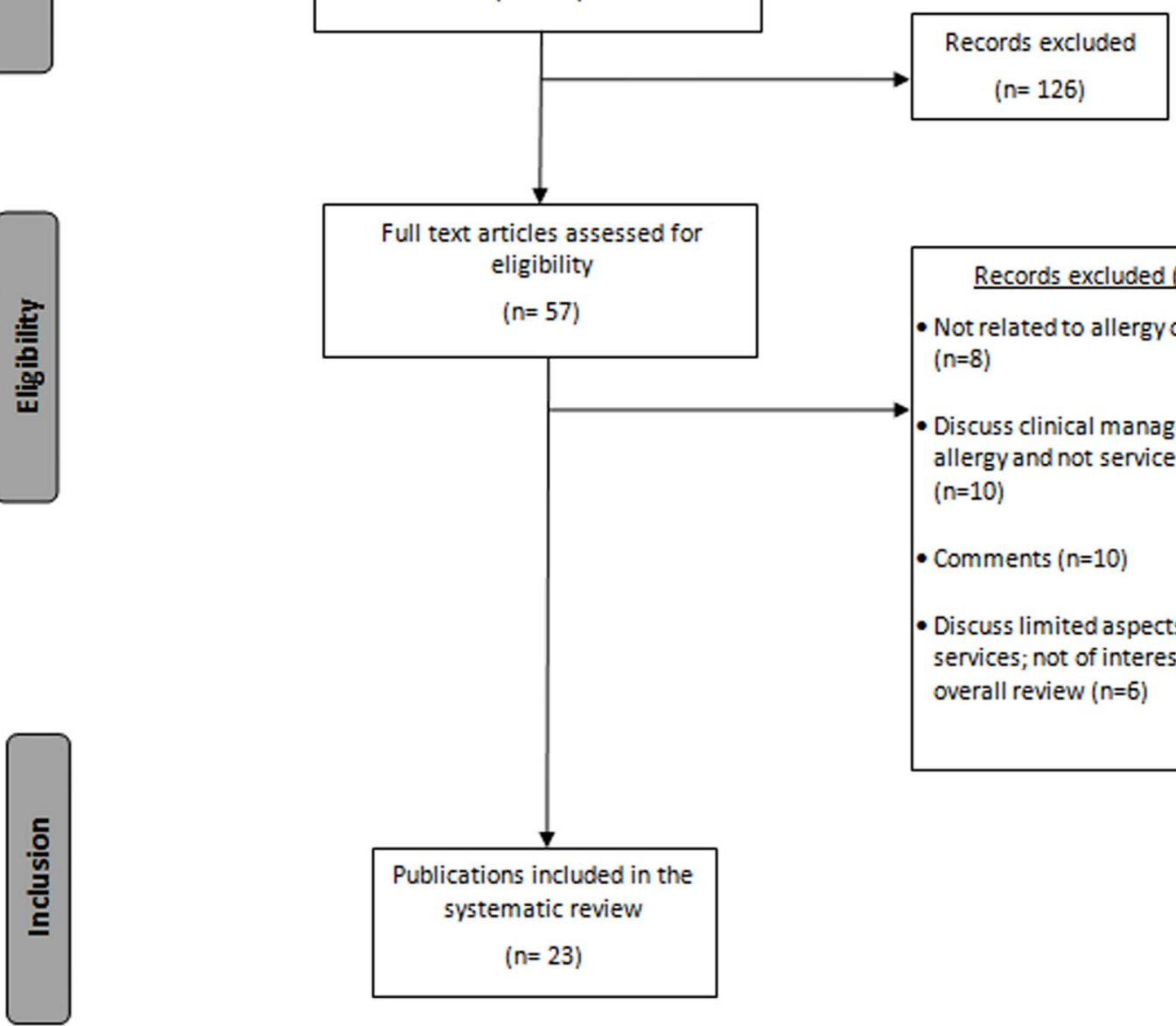

Records excluded ( $n=34)$

- Not related to allergy or eczema $(n=8)$

- Discuss clinical management of allergy and not service delivery $(n=10)$

- Comments $(n=10)$

- Discuss limited aspects of allergy services; not of interest to the overall review $(n=6)$

Figure 1 Flow diagram showing the stages involved in choosing eligible publications for the systematic review (based on the PRISMA recommendations).

\section{RESULTS}

The database search identified 351 articles of which 158 were duplicates. Additional 12 articles were included following reference and citation searches. After consideration of the title and abstract, a further 142 articles were excluded and a total of 63 publications were screened thoroughly for their relevance to the review. Figure 1 shows a flow diagram of the papers screened, identified, retained or excluded at each stage, and the reasons for exclusion of articles as per the PRISMA guidelines. ${ }^{35}$

Twenty-seven publications were included in the final review which are summarised in table 1. Only three publications describe prospective data collection alongside service reorganisation. ${ }^{23} 4352$ There were no eligible prospective, randomised controlled trials identified. 


\begin{tabular}{|c|c|c|c|c|c|c|c|}
\hline Author, (year) (ref) & Region & Type of study & Study aim & $\frac{\text { Level }}{1^{\circ} 2^{\circ}}$ & Salient findings & Key recommendations & Comments \\
\hline $\begin{array}{l}\text { Isinkaye et al } \\
(2016)^{36}\end{array}$ & UK & $\begin{array}{l}\text { Retrospective cohort } \\
\text { study }\end{array}$ & $\begin{array}{l}\text { To ascertain what } \\
\text { proportion of referrals to } \\
\text { secondary care could be } \\
\text { managed a by GP with } \\
\text { special interest in allergy }\end{array}$ & $\checkmark$ & $\begin{array}{l}\text { At least two-fifths of all } \\
\text { referrals to specialists } \\
\text { (42\%) were felt to be } \\
\text { appropriate for a GPwSI } \\
\text { setting. } \\
\text { There was some } \\
\text { disagreement between } \\
\text { reviewers re: suitability of a } \\
\text { further } 30 \% \text { of the referrals } \\
\text { Intraobserver variation was } \\
\text { also seen (ie, reviewer } \\
\text { changed their initial opinion } \\
\text { on referral after seeing the } \\
\text { letter from specialist). }\end{array}$ & $\begin{array}{l}\text { GPwSI in allergy could } \\
\text { effectively identify and } \\
\text { manage a large proportion } \\
\text { of referrals made to } \\
\text { paediatric allergy } \\
\text { specialists. } \\
\text { This service should be } \\
\text { introduced alongside other } \\
\text { initiatives to improve UK } \\
\text { allergy services. }\end{array}$ & $\begin{array}{l}\text { The GP referral letters and the } \\
\text { clinic letters from specialists } \\
\text { were reviewed by three } \\
\text { paediatric allergists. } \\
\text { Generalisability of results may } \\
\text { be an issue, although GPwSI } \\
\text { shown to be useful by Levy } \\
\text { et al as well. } \\
\text { The authors used an agreed } \\
\text { set of criteria for the } \\
\text { competencies expected of a } \\
\text { GPwSI (not provided with the } \\
\text { paper). }\end{array}$ \\
\hline $\begin{array}{l}\text { Krishna et al } \\
(2016)^{37}\end{array}$ & UK & $\begin{array}{l}\text { Report/non-systematic } \\
\text { literature review }\end{array}$ & $\begin{array}{l}\text { To discuss the potential } \\
\text { use of telemedicine in } \\
\text { pathways for diagnosis } \\
\text { and management of adult } \\
\text { allergies }\end{array}$ & $\checkmark \checkmark$ & $\begin{array}{l}\text { Adult allergy services can } \\
\text { potentially benefit from } \\
\text { telemedicine. Various } \\
\text { pathways are suggested. } \\
\text { Algorithms for possible } \\
\text { management of allergic } \\
\text { rhinitis, urticaria and } \\
\text { anaphylaxis via } \\
\text { telemedicine are discussed }\end{array}$ & $\begin{array}{l}\text { Authors advise that } \\
\text { prospective studies evaluating } \\
\text { these techniques should be } \\
\text { planned }\end{array}$ & $\begin{array}{l}\text { Telemedicine used } \\
\text { successfully in some areas of } \\
\text { medicine, but systematic } \\
\text { prospective studies in allergy } \\
\text { are lacking. } \\
\text { There are potential issues with } \\
\text { clinical governance and } \\
\text { confidentiality Lack of } \\
\text { adequately trained specialists } \\
\text { can affect implementation of } \\
\text { these measures. }\end{array}$ \\
\hline $\begin{array}{l}\text { Bousquet et al } \\
(2015)^{38}\end{array}$ & Europe & $\begin{array}{l}\text { Introduction of } \\
\text { prospective study } \\
\text { using Information and } \\
\text { communications } \\
\text { technology (ICT) } \\
\text { methods. }\end{array}$ & $\begin{array}{l}\text { Plan for study with ICT } \\
\text { methods in allergy } \\
\text { services. }\end{array}$ & $\checkmark \checkmark$ & $\begin{array}{l}\text { Many gaps in allergy } \\
\text { diagnosis and management } \\
\text { exist which could be } \\
\text { addressed using advances } \\
\text { in ICT. } \\
\text { The use of Visual Analog } \\
\text { scoring, e-allergy and } \\
\text { MASK aerobiology apps } \\
\text { can help in diagnosis, } \\
\text { management and } \\
\text { monitoring of allergic } \\
\text { rhinitis. }\end{array}$ & $\begin{array}{l}\text { The systems will be based } \\
\text { on ARIA and International } \\
\text { consensus of rhinitis } \\
\text { guidelines. } \\
\text { The use of ICT can } \\
\text { facilitate communication } \\
\text { between clinicians, } \\
\text { patients, pharmacists and } \\
\text { other stakeholders. }\end{array}$ & $\begin{array}{l}\text { This project aims to use ICT } \\
\text { systems to tackle } \\
\text { heterogeneity in AR } \\
\text { management across Europe. } \\
\text { The clinical trial is being } \\
\text { planned; but the uptake of ICT } \\
\text { in other studies has been poor. }\end{array}$ \\
\hline $\begin{array}{l}\text { Conlan et al } \\
(2015)^{39}\end{array}$ & Ireland & $\begin{array}{l}\text { Retrospective cohort } \\
\text { study }\end{array}$ & $\begin{array}{l}\text { Review of } \\
\text { 1. New allergy referrals to } \\
\text { adult specialist clinic. } \\
\text { 2. A pilot email } \\
\text { communication service } \\
\text { with non-specialists. }\end{array}$ & $\checkmark \checkmark$ & $\begin{array}{l}\text { A majority of patients } \\
\text { referred to secondary care } \\
\text { had chronic spontaneous } \\
\text { urticaria or angioedema. } \\
\text { Food/drug allergy or } \\
\text { intolerance accounted for } \\
\text { about a quarter of all } \\
\text { referrals. }\end{array}$ & $\begin{array}{l}\text { Studies examining referral } \\
\text { patterns can be helpful in } \\
\text { planning services locally by } \\
\text { targeting education of } \\
\text { non-specialists. } \\
\text { New models of care } \\
\text { delivery should be tried to }\end{array}$ & $\begin{array}{l}\text { Study designed to help service } \\
\text { planning locally design may be } \\
\text { generalisable whereas findings } \\
\text { are not. } \\
\text { The uptake of email service } \\
\text { was perhaps lower than } \\
\text { expected. Also the response } \\
\text { rate to the survey was poor }\end{array}$ \\
\hline
\end{tabular}




\begin{tabular}{|c|c|c|c|c|c|c|c|}
\hline \multirow[b]{2}{*}{ Author, (year) (ref) } & \multirow[b]{2}{*}{ Region } & \multirow[b]{2}{*}{ Type of study } & \multirow[b]{2}{*}{ Study aim } & Level & \multirow{2}{*}{ Salient findings } & \multirow[b]{2}{*}{ Key recommendations } & \multirow[b]{2}{*}{ Comments } \\
\hline & & & & $\overline{1^{\circ} 2^{\circ}}$ & & & \\
\hline & & & & & $\begin{array}{l}\text { The email service did not } \\
\text { show demonstrable impact } \\
\text { on referral numbers. } \\
\text { It was rated as useful by } \\
\text { those clinicians who } \\
\text { responded to the survey. }\end{array}$ & $\begin{array}{l}\text { help ease demand on } \\
\text { specialist allergy centres. }\end{array}$ & $\begin{array}{l}\text { ( } 35 \%) \text { which makes the } \\
\text { usefulness of the service } \\
\text { difficult to gauge. }\end{array}$ \\
\hline Chan et al $(2015)^{40}$ & $\begin{array}{l}\text { Hong } \\
\text { Kong }\end{array}$ & Report & $\begin{array}{l}\text { To discuss the current } \\
\text { management of allergic } \\
\text { disease in Hong Kong. }\end{array}$ & $\checkmark$ & $\begin{array}{l}\text { Despite increasing demand, } \\
\text { allergy services and training } \\
\text { remain poor. There are } \\
\text { dedicated allergy services } \\
\text { in public hospitals for } \\
\text { adults. } \\
\text { Laboratory support for } \\
\text { allergy and immunology is } \\
\text { inadequate. }\end{array}$ & $\begin{array}{l}\text { } 2 \text { pilot 'Hub and spoke' } \\
\text { centres catering for adult } \\
\text { and paediatric allergy } \\
\text { should be established. } \\
\text { Training programme in } \\
\text { paediatric and adult } \\
\text { immunology and infectious } \\
\text { diseases should be } \\
\text { extended to allergy. }\end{array}$ & $\begin{array}{l}\text { This is a report from the Hong } \\
\text { Kong allergy alliance, whose } \\
\text { members include patients, } \\
\text { clinicians, academics, industry } \\
\text { and other stake holders in allergy } \\
\text { within Hong Kong. }\end{array}$ \\
\hline Jutel et al (2013) & Europe & Report/cross-section & $\begin{array}{l}\text { To provide a contextual } \\
\text { patient-centric framework } \\
\text { based on opinion of PCPs, } \\
\text { specialists and patients. }\end{array}$ & $\checkmark$ & $\begin{array}{l}\text { Access to specialist } \\
\text { services was identified as } \\
\text { the 'greatest unmet need'. } \\
\text { In public health services, } \\
\text { waiting time for secondary } \\
\text { care is usually }>6 \text { weeks. } \\
\text { Current dominant model of } \\
\text { allergy care in Europe is } \\
\text { specialist based, but this is } \\
\text { unsustainable. }\end{array}$ & $\begin{array}{l}\text { Groups across Europe } \\
\text { need to learn from shared } \\
\text { experiences to generate } \\
\text { political will to enable } \\
\text { change to services. } \\
\text { Patient involvement and } \\
\text { empowerment should be } \\
\text { strongly encouraged. }\end{array}$ & $\begin{array}{l}\text { The authors of this publication } \\
\text { belong to the EAACI Task Force } \\
\text { for Allergy Management in } \\
\text { Primary Care. }\end{array}$ \\
\hline Jones et al $(2013)^{41}$ & UK & Survey/retrospective & $\begin{array}{l}\text { To assess patients } \\
\text { perception of usefulness of } \\
\text { the secondary allergy } \\
\text { clinic at Plymouth Hospital. }\end{array}$ & $\checkmark$ & $\begin{array}{l}\text { A third of the patients did } \\
\text { not find the clinic useful. } \\
\text { Half continued to have } \\
\text { troublesome symptoms. } \\
10 \% \text { do not feel confident } \\
\text { about managing their } \\
\text { allergies. }\end{array}$ & $\begin{array}{l}\text { There is a need for } \\
\text { follow-up of most patients } \\
\text { with allergy to reinforce } \\
\text { education. } \\
\text { Specialist clinics should try } \\
\text { to obtain routine feedback } \\
\text { from patients to monitor } \\
\text { effectiveness. }\end{array}$ & $\begin{array}{l}\text { Patients who attended clinic } \\
\text { over a } 11 \text { year period were } \\
\text { surveyed, } 36 \% \text { response rate } \\
\text { (336/933). } \\
\text { No description of services } \\
\text { offered or the competencies of } \\
\text { the clinicians. }\end{array}$ \\
\hline $\begin{array}{l}\text { Agache et al } \\
(2012)^{7}\end{array}$ & Europe & Survey/cross-section & $\begin{array}{l}\text { To assess the actual } \\
\text { status of allergy } \\
\text { management in primary } \\
\text { care across Europe }\end{array}$ & $\checkmark$ & $\begin{array}{l}\text { Two-thirds of PCPs do not } \\
\text { have ready access to } \\
\text { allergy specialists. } \\
\text { The average waiting time to } \\
\text { see a specialist in a public } \\
\text { health service was more } \\
\text { than } 6 \text { weeks. } \\
\text { Referring patients to organ } \\
\text { specialists is much easier } \\
\text { than referral to an allergist. }\end{array}$ & $\begin{array}{l}\text { A thorough assessment } \\
\text { needed to understand } \\
\text { demands on services and } \\
\text { facilities available to PCPs. } \\
\text { This can be used to adapt } \\
\text { allergy pathways for } \\
\text { primary care. } \\
\text { To develop a structured } \\
\text { development and } \\
\text { information platform for } \\
\text { PCPs. }\end{array}$ & $\begin{array}{l}\text { The study was carried out by } \\
\text { an EAACI task force. } \\
\text { Surveys sent to the national } \\
\text { societies of EAACI member } \\
\text { countries and to individual } \\
\text { members of EAACI as well as } \\
\text { the international primary } \\
\text { respiratory group. }\end{array}$ \\
\hline
\end{tabular}

The email service did not on referral numbers.

It was rated as useful responded to the survey.

increasing demand, remain poor. There are dedicated allergy services adults.

bervices, care is usually $>6$ weeks.

Current dominant model of allergy care in Europe is unsustainable.

the patients

oublesome symptom allergies.

Two-thirds of PCPs do no specialists is much easier
than referral to an allergist. 


\begin{tabular}{ll}
\hline Author, (year) (ref) & Region \\
\hline Sinnott et al & UK
\end{tabular}

$(2011)^{23}$

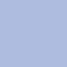

Warner and Lloyd UK

$(2011)^{42}$

Royal College of UK Report from a publicly Recommendations to

Physicians and the funded organisation. stakeholders in allergy for

Royal College of

Pathologists

$(2010)^{21}$ provision of cost-effective improvements in allergy care.

An update on changes to allergy service provision following the House of Lords inquiry (2007) into allergy.
Background for the Paediatrics and Child Health $(\mathrm{RCPCH})$ development of paediatric the Royal College of
Level

$1^{\circ}$

$\checkmark$ Poor training of PCPs leads

to inappropriate referrals due to lack of confidence in managing allergies.

- Specialist services are often deluged with patients who could have been managed in primary care.

- Variable tariffs for allergy pose a disincentive for trusts to develop services.

- Postcode lottery exists especially for those with severe allergies.

$\checkmark \checkmark \checkmark$ The pathways are aimed at commissioners, health professionals, patients, parents and carers.

- They aim to provide a bench-mark for service provision.

Key recommendations

Comments

Linking clinicians with an interest in allergy is a good way to improve standards and increase awareness of

$£ 1.8$ million pump priming for patient pathways.

- Developments should support existing service provision.

- Commissioners need to be educated regarding the impact of allergies.

- Good transition between adult and paediatric services needed.

- Eight pathways developed by six multidisciplinary working groups.

- The authors define competencies rather than criteria for onward referral, so that guidance can be applicable even when there are regional variations in service provision

- Services should join up to serve the population of a defined geographic area.

highly inequitable.

- Some progress since 2007 - Additional trainees in adult and paediatric allergy were appointed.

- The Northwest SHA spearheaded a pilot into restructuring of allergy services.

- NICE had adopted a few projects for issuance of guidelines.

- Some areas of concern remained unaddressed including:

- Poor coding of allergy clinical work.

- Patient engagement underused
- Validated Patient Reported

Outcome Measures (PROMs) need to be developed to evaluate the effectiveness of services.

- Quality Assurance schemes should be developed for clinical allergy services.

- Protocols and guidelines should be shared freely between centres.

- More allergy training should be incorporated into PCP and medical student curriculum (and all other related specialty training) 


\begin{tabular}{|c|c|c|c|c|c|c|c|}
\hline Author, (year) (ref) & Region & Type of study & Study aim & $\frac{\text { Level }}{1^{\circ} 2^{\circ}}$ & Salient findings & Key recommendations & Comments \\
\hline & & & & & $\begin{array}{l}\text { - Governance and training } \\
\text { within existing services } \\
\text { remains poor. } \\
\text { - Occupational allergy } \\
\text { provision remains poor. } \\
\text { Serious deficiencies found } \\
\text { in the commissioner's } \\
\text { knowledge of the allergy } \\
\text { needs of the local } \\
\text { population. } \\
\text { PCP survey in } 2009 \\
\text { showed that most (70\%) } \\
\text { continued to rate NHS } \\
\text { allergy services as poor } \\
\text { (similar to } 2002 \text { survey). }\end{array}$ & $\begin{array}{l}\text { Clinical services should } \\
\text { establish good links with } \\
\text { the local patient groups. } \\
\text { There should be better } \\
\text { allergen labelling. }\end{array}$ & \\
\hline Levy et al (2009) ${ }^{43}$ & UK & $\begin{array}{l}\text { Prospective; no } \\
\text { control group. }\end{array}$ & $\begin{array}{l}\text { Evaluation of a PCP with } \\
\text { special interest clinic in } \\
\text { allergy. }\end{array}$ & $\checkmark$ & $\begin{array}{l}\text { Two-thirds of the patients } \\
\text { would have been referred to } \\
\text { secondary care in the } \\
\text { absence of this clinic. } \\
\text { Less than } 10 \% \text { of those } \\
\text { reviewed were referred onto } \\
\text { a tertiary clinic. } \\
\text { The clinic was estimated to } \\
\text { have saved } £ 13,500 \text { in } \\
9 \text { months due to reduced } \\
\text { referrals. }\end{array}$ & $\begin{array}{l}\text { Second-tier clinic in } \\
\text { primary care has the } \\
\text { potential to be clinically } \\
\text { effective as well as } \\
\text { cost-effective. } \\
\text { It encourages care in the } \\
\text { local community and can } \\
\text { reduce the burden of } \\
\text { inappropriate referrals to } \\
\text { tertiary centres. }\end{array}$ & $\begin{array}{l}\text { Referrals proforma provided } \\
\text { information on how the clinic } \\
\text { was used by other PCPs. } \\
\text { Consultation satisfaction } \\
\text { questionnaire captured patient } \\
\text { experience. }\end{array}$ \\
\hline $\begin{array}{l}\text { Working group of } \\
\text { the Scottish Medical } \\
\text { and Scientific } \\
\text { Advisory Committee } \\
(2009)^{22}\end{array}$ & UK & $\begin{array}{l}\text { Report from a publicly } \\
\text { funded organisation. }\end{array}$ & $\begin{array}{l}\text { To report on the diagnostic } \\
\text { and clinical allergy } \\
\text { services within Scotland }\end{array}$ & & $\begin{array}{l}\text { High burden of allergy in } \\
\text { Scotland; } 30 \% \text { children and } \\
25 \% \text { adults are affected. } \\
\text { The levels are rising for all } \\
\text { conditions (except perhaps } \\
\text { asthma) and services have } \\
\text { only improved marginally } \\
\text { since last report in } 2000 \text {. } \\
\text { There are insufficient } \\
\text { numbers of medical } \\
\text { specialists, trainees, PCPs, } \\
\text { dieticians, nurses and } \\
\text { pharmacists trained in } \\
\text { allergy. } \\
\text { Service is fragmented with } \\
\text { no collaboration between } \\
\text { primary, secondary and } \\
\text { tertiary services. }\end{array}$ & $\begin{array}{l}\text { Primary care staff should } \\
\text { have access to basic initial } \\
\text { and ongoing training. } \\
\text { There is a need to } \\
\text { encourage and facilitate } \\
\text { standardised and } \\
\text { evidence-based practice } \\
\text { through shared protocols } \\
\text { and pathways. } \\
\text { Data collection, audit and } \\
\text { research facilities in allergy } \\
\text { should be improved to } \\
\text { ensure better future } \\
\text { planning of services. } \\
\text { Regional MCN for adult } \\
\text { allergy and a national MCN } \\
\text { for paediatric allergy } \\
\text { services are needed. }\end{array}$ & $\begin{array}{l}\text { The authors commented on } \\
\text { the non-availability of trained } \\
\text { specialists and the } \\
\text { underusage of non-physician } \\
\text { services for allergy } \\
\text { (pharmacists, dieticians, nurse } \\
\text { specialists). } \\
\text { Improved motivation via } \\
\text { incentives should be planned. } \\
\text { PCP with special interest may } \\
\text { be a useful resource. }\end{array}$ \\
\hline
\end{tabular}




Author, (year) (ref) Region Type of study Study aim $\quad$ Level

Author, (year) (ref) Region

with clinician support.

the deficiencies in service.

Allergy curriculum in

postgraduate medi

training needs improving

Haahtela et al $(2008)^{32}$

Finland

Prospective; intervention; no control group.

Nationwide allergy programme being adopted in Finland. Proposed to run between 2008 and 2018.
House of Lords

Science and

Technology

Committee, 6th

report of session

2006/7 (2007) ${ }^{18}$
UK

Report from a publicly
funded organisation

re the impact of

allergy in the UK upon

patients, society and the economy as a whole. $\checkmark \checkmark$ Project is currently underway. Its goals include:

- Prevention of allergic symptoms.

- Increase tolerance against allergens.

- Improve allergy diagnostics.

- Increase resources for allergy management.

- Decrease healthcare costs due to allergies.

\section{Allergy exerts a} considerable social and economic burden upon the nation.

- There is a severe shortage of allergy specialists in the UK and the services lag far behind those of many countries in Western Europe.

- There are problems with data collection rendering statistics imprecise and affecting service redevelopment plans.

- There has been a chronic lack of training of PCPs and medical trainees in allergy, leading to problems with diagnosis and managemen at the primary care level.
- For each of the five identified goals, specific tasks, tools and evaluation methods have been defined.

- This project is based on very close collaboration between the government, healthcare sector and non-governmental organisations.

- Emphasis is on tolerance and not on allergen avoidance.

- Improved education of medical practitioners to diagnose and treat occupational allergies needed.

- Improve undergraduate and PCP allergy training.

- New centres should build on existing excellence.

- Some specialist services can be restricted to few centres across the country.

- Educators and

Commissioners should work together to develop generic quality assured clinical post graduate allergy courses.

- NICE to appraise immunotherapy and cost-effectiveness.
- The project builds on the very successful Finnish asthma model.

- Being followed in other countries (Norway, UK), preliminary results are expected soon.

- This report was published by the allergy subcommittee UK House of Lords Science and Technology Committee 2007.

- Recommendations made for non-NHS management of allergies (eg, training teachers in managing allergic emergencies, supporting children with hay fever during school examinations, helping those with occupational allergies return to work, improving allergen food labelling, etc).

- Authors visited numerous national and international allergy centres of repute to compile this report. 


\begin{tabular}{|c|c|c|c|c|c|c|c|}
\hline Author, (year) (ref) & Region & Type of study & Study aim & $\frac{\text { Level }}{1^{\circ} 2^{\circ}}$ & Salient findings & Key recommendations & Comments \\
\hline & & & & & $\begin{array}{l}\text { Further research into the } \\
\text { basis of allergy is urgently } \\
\text { needed to underpin further } \\
\text { public health policies to } \\
\text { address the rise the } \\
\text { allergies. } \\
\text { Large, tertiary centres led } \\
\text { by allergists should be } \\
\text { developed to ensure } \\
\text { optimal treatment of } \\
\text { patients with complex and } \\
\text { severe disease and also as } \\
\text { sources for education and } \\
\text { training for other clinicians. }\end{array}$ & $\begin{array}{l}\text { A lead health authority } \\
\text { should be identified by the } \\
\text { Department of Health in } \\
\text { order to establish a pilot } \\
\text { tertiary allergy centre. A full } \\
\text { cost analysis should be } \\
\text { integral to its } \\
\text { establishment. }\end{array}$ & \\
\hline $\begin{array}{l}\text { Department of } \\
\text { Health }(2007)^{44}\end{array}$ & UK & $\begin{array}{l}\text { Report from a publicly } \\
\text { funded organisation. }\end{array}$ & $\begin{array}{l}\text { Response to the report } \\
\text { from the House of Lords } \\
\text { Science and Technology } \\
\text { Committee } 2007 \text {. }\end{array}$ & $\checkmark \checkmark$ & $\begin{array}{l}\text { No published whole system } \\
\text { models of services for } \\
\text { people with allergy. } \\
\text { No data on existing skills. } \\
\text { There are also no analyses } \\
\text { of effects of active demand } \\
\text { management of patient } \\
\text { flows in allergy care. } \\
\text { No data on allergy needs in } \\
\text { various regions across the } \\
\text { country. }\end{array}$ & $\begin{array}{l}\text { The royal colleges should } \\
\text { work together to set up } \\
\text { curricula for health } \\
\text { professional training in } \\
\text { allergy. } \\
\text { Health commissioners } \\
\text { should work with local } \\
\text { service providers to ensure } \\
\text { best possible service } \\
\text { planning for their } \\
\text { catchment areas. } \\
\text { Much clearer } \\
\text { understanding of skills and } \\
\text { competencies of the } \\
\text { existing workforce needed. } \\
\text { NICE advised to provide } \\
\text { guidance on allergen } \\
\text { immunotherapy. }\end{array}$ & $\begin{array}{l}\text { Funding identified for an } \\
\text { allergy centre in the North } \\
\text { West region of England. } \\
\text { Most of the recommendations } \\
\text { from the House of Lords report } \\
\text { could not be acted upon due to } \\
\text { insufficient and unreliable data } \\
\text { on the existing state of allergy } \\
\text { management, according to this } \\
\text { report. }\end{array}$ \\
\hline Warner et al (2006) & Worldwide & $\begin{array}{l}\text { Cross-section; } \\
\text { Questionnaire survey. }\end{array}$ & $\begin{array}{l}\text { To define the current state } \\
\text { of allergy training and } \\
\text { services in the countries } \\
\text { represented within the } \\
\text { WAO }\end{array}$ & $\checkmark$ & $\begin{array}{l}\text { Prevalence rates for } \\
\text { allergies in the responding } \\
\text { countries ranged from } 7.5 \% \\
\text { to } 40 \% \text { (mean } 22 \% \text { ). } \\
\text { Number of certified } \\
\text { allergists varied widely from } \\
1: 25 \text { million in Indonesia to } \\
1: 16,000 \text { in Germany. } \\
\text { Formal certification } \\
\text { procedure is not available } \\
\text { for clinicians in some of the } \\
\text { countries surveyed. }\end{array}$ & $\begin{array}{l}\text { There is a very wide gap } \\
\text { between demand and } \\
\text { provision of allergy } \\
\text { services worldwide. } \\
\text { Training of medical } \\
\text { students, general } \\
\text { practitioners, generalists as } \\
\text { well as system specialists } \\
\text { who deal with allergy must } \\
\text { improve to ensure better } \\
\text { care provision. }\end{array}$ & $\begin{array}{l}\text { Survey sent to all WAO } \\
\text { national society member } \\
\text { organisations to be completed } \\
\text { by allergists knowledgeable } \\
\text { about services within their own } \\
\text { countries ( } 61 \text { sent, } 34 \\
\text { responses received). } \\
\text { Data based on impressions of } \\
\text { these experts in some } \\
\text { countries rather than on } \\
\text { published data. }\end{array}$ \\
\hline
\end{tabular}

Further research into the public health policies to allergies.

Large, tertiary centres led y allergists should be optimal treatment of patients with complex and severe disease and also as sources for education and

models of services for management of patient various regions across the

NICE advised to provide ce on allergen

allergies in the responding countries ranged from $7.5 \%$

allergists varied widely from 1:25 million in Indonesia to

in Germany.

procedure is not available countries surveyed. 


\begin{tabular}{|c|c|c|c|c|c|c|c|}
\hline Author, (year) (ref) & Region & Type of study & Study aim & $\frac{\text { Level }}{1^{\circ} 2^{\circ}}$ & Salient findings & Key recommendations & Comments \\
\hline & & & & & $\begin{array}{l}\text { In most countries, patients } \\
\text { are first referred to } \\
\text { organ-based specialists } \\
\text { before being referred to } \\
\text { allergists. }\end{array}$ & $\begin{array}{l}\text { More tertiary level centres } \\
\text { needed to set the } \\
\text { standards, advance } \\
\text { research, support training } \\
\text { and provide expertise to } \\
\text { primary and secondary } \\
\text { care. }\end{array}$ & \\
\hline $\begin{array}{l}\text { Department of } \\
\text { Health (2006) }\end{array}$ & UK & $\begin{array}{l}\text { Report from a publicly } \\
\text { funded organisation. }\end{array}$ & $\begin{array}{l}\text { Review of allergy services } \\
\text { undertaken to fulfil } \\
\text { Government of UK's } \\
\text { commitment to the House } \\
\text { of Commons Health } \\
\text { Committee. }\end{array}$ & $\checkmark \checkmark$ & $\begin{array}{l}\text { No compelling evidence on } \\
\text { need or on quality of allergy } \\
\text { services since relevant } \\
\text { research lacking. } \\
\text { Patients feel let down by a } \\
\text { poor and often inaccessible } \\
\text { service. } \\
\text { Specialist services are } \\
\text { usually not available, } \\
\text { resulting in very long waits } \\
\text { to see consultants where } \\
\text { services do exist. } \\
\text { Self-care can be particularly } \\
\text { useful in allergy and should } \\
\text { be promoted. } \\
\text { Some conflict between the } \\
\text { main two specialities } \\
\text { offering allergy services in } \\
\text { the UK (ie, allergy and } \\
\text { clinical immunology). }\end{array}$ & $\begin{array}{l}\text { Local commissioners need } \\
\text { to establish levels of need } \\
\text { for services for allergy in } \\
\text { their health community. } \\
\text { Educators and } \\
\text { Commissioners should } \\
\text { work together to create } \\
\text { additional training spaces } \\
\text { for doctors. } \\
\text { Guidelines for } \\
\text { management and care } \\
\text { pathways should be } \\
\text { developed by NICE. }\end{array}$ & $\begin{array}{l}\text { Data obtained by review of } \\
\text { existing literature and also by } \\
\text { interviewing stakeholders. } \\
\text { Highlights the difficulties in } \\
\text { developing national strategy for } \\
\text { allergy services without } \\
\text { baseline data on needs and } \\
\text { costs involved. } \\
\text { It is important to understand } \\
\text { the skills and competencies } \\
\text { that exist and those that are } \\
\text { needed from the diverse } \\
\text { workforce to enable future } \\
\text { development and provision of } \\
\text { services. }\end{array}$ \\
\hline $\begin{array}{l}\text { El-Shanawany et al } \\
(2005)^{46}\end{array}$ & UK & $\begin{array}{l}\text { Cross-section; } \\
\text { Questionnaire Survey }\end{array}$ & $\begin{array}{l}\text { To survey allergy services } \\
\text { provided by clinical } \\
\text { immunologists in the UK. }\end{array}$ & v & $\begin{array}{l}\text { Immunology centres are the } \\
\text { only providers of tertiary } \\
\text { allergy care for most of the } \\
\text { UK. } \\
\text { Consultant immunologists } \\
\text { are likely to be providers of } \\
\text { tertiary level allergy care in } \\
\text { the medium and long term } \\
\text { for the UK. } \\
\text { Waiting times for allergy } \\
\text { patients in these clinics } \\
\text { were long, sometimes } \\
\text { waiting over a year for } \\
\text { urgent appointments. } \\
\text { Very few centres benefitted } \\
\text { from dietician support. }\end{array}$ & $\begin{array}{l}\text { There needs to be a } \\
\text { collaborative effort between } \\
\text { clinical immunologists and } \\
\text { allergists in the UK in order } \\
\text { to improve services. }\end{array}$ & $\begin{array}{l}\text { Questionnaires sent via three } \\
\text { supra-regional immunology } \\
\text { audit groups to the various } \\
\text { participating immunology } \\
\text { regional centres in the country. } \\
17 \text { immunology centres serving } \\
\text { a total population of } 32 \text { million } \\
\text { individuals responded. }\end{array}$ \\
\hline
\end{tabular}




\begin{tabular}{|c|c|c|c|c|c|c|c|}
\hline \multirow[b]{2}{*}{ Author, (year) (ref) } & \multirow[b]{2}{*}{ Region } & \multirow[b]{2}{*}{ Type of study } & \multirow[b]{2}{*}{ Study aim } & Level & \multirow{2}{*}{ Salient findings } & \multirow[b]{2}{*}{ Key recommendations } & \multirow[b]{2}{*}{ Comments } \\
\hline & & & & $\overline{1^{\circ} 2^{\circ}}$ & & & \\
\hline Ryan et al (2005) ${ }^{47}$ & UK & Discussion & $\begin{array}{l}\text { To propose minimum } \\
\text { levels of knowledge } \\
\text { required for clinicians in } \\
\text { order to improve standards } \\
\text { of allergy care. }\end{array}$ & $\checkmark \checkmark$ & $\begin{array}{l}\text { Self-care in allergy is } \\
\text { problematic due to the poor } \\
\text { access to NHS healthcare } \\
\text { and the availability of } \\
\text { unregulated alternate } \\
\text { practitioners. } \\
\text { PCPs and practice nurses } \\
\text { could be better trained in } \\
\text { prescribing drugs for } \\
\text { allergy. }\end{array}$ & $\begin{array}{l}\text { Intermediate care services } \\
\text { (eg, PCP with special } \\
\text { interest) should be } \\
\text { developed. } \\
\text { Pharmacists, primary care } \\
\text { nurses and physicians } \\
\text { could be trained in a few } \\
\text { allergy-related techniques } \\
\text { to vastly improve service } \\
\text { provision. }\end{array}$ & $\begin{array}{l}\text { The authors suggest that } \\
\text { management of allergy in } \\
\text { primary care can be improved } \\
\text { even when specific tests and } \\
\text { other infrastructure are } \\
\text { unavailable. } \\
\text { Knowledge of } \\
\text { pharmacotherapy for allergy } \\
\text { can help PCPs manage a } \\
\text { majority of patients. }\end{array}$ \\
\hline $\begin{array}{l}\text { Department of } \\
\text { Health }(2005)^{48}\end{array}$ & UK & $\begin{array}{l}\text { Report from a publicly } \\
\text { funded organisation }\end{array}$ & $\begin{array}{l}\text { Government of UK } \\
\text { response to the House of } \\
\text { Commons Health } \\
\text { Committee report. }\end{array}$ & $\checkmark \checkmark$ & $\begin{array}{l}\text { Good quality data on needs } \\
\text { and services for allergy is } \\
\text { lacking. } \\
\text { Service models for } \\
\text { managing allergy in primary } \\
\text { and secondary care could } \\
\text { be developed. } \\
\text { Medical regulatory bodies } \\
\text { overseeing physician and } \\
\text { nurse training should be } \\
\text { encouraged to increase } \\
\text { allergy educational content } \\
\text { during training. }\end{array}$ & $\begin{array}{l}\text { Self-care should be } \\
\text { encouraged; NHS led } \\
\text { expert patient programme } \\
\text { will be extended to allergy. } \\
\text { Food Standards Agency } \\
\text { has produced a guide for } \\
\text { those recently diagnosed } \\
\text { with food allergies. } \\
\text { Local commissioners } \\
\text { should establish need for } \\
\text { services in their local area. }\end{array}$ & $\begin{array}{l}\text { It was felt that a review of } \\
\text { available data and research on } \\
\text { allergic conditions is necessary } \\
\text { in order to plan future direction } \\
\text { of allergy services. This formed } \\
\text { the basis for a separate report } \\
\text { (as above). }\end{array}$ \\
\hline Levy et al (2004) $)^{49}$ & UK & $\begin{array}{l}\text { Cross-section; } \\
\text { Questionnaire survey }\end{array}$ & $\begin{array}{l}\text { Understanding the views } \\
\text { of PCPs in the UK } \\
\text { regarding the quality of } \\
\text { primary and secondary } \\
\text { care for allergy. }\end{array}$ & $\checkmark$ & $\begin{array}{l}\text { More than } 80 \% \text { felt that the } \\
\text { NHS allergy care was poor. } \\
\text { Primary and secondary } \\
\text { care services were thought } \\
\text { to be deficient. } \\
\text { Very few (4\%) offered skin } \\
\text { prick tests at their practice. } \\
\text { Most expressed concern } \\
\text { regarding managing } \\
\text { children with allergies. } \\
\text { A majority were confident in } \\
\text { the management of } \\
\text { urticaria, allergic rhinitis, } \\
\text { angioedema, anaphylaxis. }\end{array}$ & $\begin{array}{l}\text { National education } \\
\text { programmes should be } \\
\text { developed for PCPs. } \\
\text { Specialist care provision for } \\
\text { allergy should be reviewed } \\
\text { urgently within the NHS. }\end{array}$ & $\begin{array}{l}\text { Randomly selected sample of } \\
500 \text { PCPs from UK General } \\
\text { Practice register were } \\
\text { contacted. } \\
\text { - Only } 50 \% \text { response rate. }\end{array}$ \\
\hline $\begin{array}{l}\text { House of Commons } \\
\text { Health Committee } \\
(2004)^{19}\end{array}$ & UK & $\begin{array}{l}\text { Report from a publicly } \\
\text { funded organisation }\end{array}$ & $\begin{array}{l}\text { To highlight the need for } \\
\text { allergy service } \\
\text { improvement in the UK }\end{array}$ & $\checkmark \checkmark$ & $\begin{array}{l}\text { Primary care skill base for } \\
\text { allergy is poor-this is } \\
\text { compounded by weakness } \\
\text { in secondary care sector as } \\
\text { well. }\end{array}$ & $\begin{array}{l}\text { Allergy specialist centres } \\
\text { need to be developed } \\
\text { manned by allergists; } \\
\text { allergists cannot be } \\
\text { substituted effectively by } \\
\text { other specialists. }\end{array}$ & $\begin{array}{l}\text { Health committee comprising } \\
\text { of elected representatives. } \\
\text { Expert interviews, statistics } \\
\text { from published sources, } \\
\text { submissions to panels from }\end{array}$ \\
\hline
\end{tabular}


Table 1 Continued

\begin{tabular}{|c|c|c|c|c|c|c|c|}
\hline Author, (year) (ref) & Region & Type of study & Study aim & $\frac{\text { Level }}{1^{\circ} 2^{\circ}}$ & Salient findings & Key recommendations & Comments \\
\hline & & & & & $\begin{array}{l}\text { Increasing emergency } \\
\text { admissions for allergy. } \\
\text { Some papers quoted to } \\
\text { suggest specialist services } \\
\text { may be cost-effective. }\end{array}$ & $\begin{array}{l}\text { There is a need for more } \\
\text { dieticians and nurse } \\
\text { specialists in allergy. }\end{array}$ & \\
\hline $\begin{array}{l}\text { Ewan and Durham } \\
(2002)^{33}\end{array}$ & UK & Discussion & $\begin{array}{l}\text { Proposal to improve NHS } \\
\text { allergy care in the UK }\end{array}$ & $\checkmark$ & $\begin{array}{l}\text { NHS allergy service } \\
\text { provision is inadequate and } \\
\text { inequitable. } \\
\text { Estimate that there is one } \\
\text { whole time equivalent } \\
\text { allergist per } 3.4 \text { million } \\
\text { population in the UK. } \\
\text { Only six clinics in the UK } \\
\text { offer services of full time } \\
\text { NHS allergists. }\end{array}$ & $\begin{array}{l}\text { Each of the health areas in } \\
\text { the UK should have a } \\
\text { regional specialist centre to } \\
\text { provide clinical expertise } \\
\text { and training. } \\
\text { More training posts in } \\
\text { allergy should be created. }\end{array}$ & $\begin{array}{l}\text { Data derived from the BSACI } \\
\text { and BAF database. } \\
\text { Authors assume that part-time } \\
\text { allergists provide } 0.3 \text { WTE and } \\
\text { other specialists provide } 0.1 \\
\text { WTE allergy work per week. } \\
\text { This is debatable. }\end{array}$ \\
\hline Ewan $(2000)^{50}$ & UK & Discussion & $\begin{array}{l}\text { An overview of NHS } \\
\text { allergy services and } \\
\text { suggestions for } \\
\text { improvement. }\end{array}$ & $\checkmark$ & $\begin{array}{l}\text { There are serious } \\
\text { deficiencies in the allergy } \\
\text { services within the UK. } \\
\text { Training numbers for allergy } \\
\text { are not adequate to serve } \\
\text { current and future demands } \\
\text { on the specialty. } \\
\text { Organ specialists (including } \\
\text { immunologists) not } \\
\text { appropriately trained for the } \\
\text { holistic management of } \\
\text { these patients. }\end{array}$ & $\begin{array}{l}\text { Minimum of } 1 \text { regional } \\
\text { allergy centre per region } \\
\text { needed manned by allergy } \\
\text { specialists and nurses, } \\
\text { dietician. } \\
\text { Organ-based specialists } \\
\text { and allergists need to be } \\
\text { appointed to more } \\
\text { secondary level centres. } \\
\text { There should be an } \\
\text { increase in specialist } \\
\text { training spaces for allergy. }\end{array}$ & $\begin{array}{l}\text { Data from } \mathrm{BSACl} \text { and BAF } \\
\text { database as above. } \\
\text { Recommendations as per the } \\
\text { Allergy task force set up by the } \\
\text { BSACl and DoH in } 1998 \text {. }\end{array}$ \\
\hline Brydon $(1993)^{51}$ & UK & $\begin{array}{l}\text { Questionnaire; } \\
\text { retrospective }\end{array}$ & $\begin{array}{l}\text { A survey to determine the } \\
\text { effectiveness of a nurse } \\
\text { practitioner service. }\end{array}$ & $\checkmark$ & $\begin{array}{l}\text { Nurse led service resulted } \\
\text { in fewer general practitioner } \\
\text { consultations and also a } \\
\text { reduction in prescribed } \\
\text { medication for allergy. } \\
\text { Most respondents reported } \\
\text { an improvement in } \\
\text { symptoms. } \\
\text { Better results seen in } \\
\text { patients who were followed } \\
\text { up for longer. }\end{array}$ & $\begin{array}{l}\text { Using nurse led services in } \\
\text { primary care can be cost } \\
\text { saving. } \\
\text { There could have been a } \\
\text { recruitment bias/criteria for } \\
\text { choosing a section of } \\
\text { patients not made explicit. }\end{array}$ & $\begin{array}{l}\text { Bespoke postal questionnaire } \\
\text { before and } 9 \text { months after } \\
\text { appointment with the nurse. } \\
\text { Responses compared with } \\
\text { patient notes from PCP. }\end{array}$ \\
\hline
\end{tabular}

BAF, British Allergy Foundation; BSACI, British Society of Allergy and Clinical Immunology; DoH, Department of Health (UK); EAACI, European Academy of Allergy and Clinical Immunology; MCN, Managed Clinical Network; NHS, National Health Service (UK); NICE, National Institute of Health and Care Excellence, UK; PCP, Primary Care Physician; PROM, Patient Reported Outcome Measures; WTE, Whole Time Equivalent; WAO, World Allergy Organisation.

Level: $1^{\circ}$ (primary) refers to care delivered by primary care physicians, nurses and other practitioners who are non-specialist and offer services in the home or community.

$2^{\circ}$ (secondary) services refer to those provided in hospitals by clinicians (doctors or nurses) deemed to have specialist training and knowledge relevant to the management of the condition. 
Seven of the publications discussed allergy services in other parts of the world, ${ }^{3} 7243238-40$ whereas the rest are focused specifically on services in the UK. Of the 19 UK papers, 8 are reports published by governmental organisations discussing the state of allergy services in the UK. ${ }^{18-22} 444548$ One of these reports provides a brief overview on aspects of allergy services in other European countries (Germany and Denmark). ${ }^{18}$ Another summarises experiences following the establishment of a pilot allergy service in the North West of England. ${ }^{23}$

Reorganisation of primary care was addressed by seven articles, secondary care services were the focus of six publications, whereas four papers discuss both levels of care. The eight government reports discuss all aspects of service delivery (table 1). Three studies discussed the use of digital technology-based interventions for allergy, ${ }^{37-39}$ one of these retrospectively evaluated such a service. ${ }^{39}$ Findings, statements and recommendations about allergy service pathways from the included papers are reported in table 1 and are synthesised thematically.

\section{Primary care services}

PCPs in allergy service delivery

PCPs are the first-line providers of healthcare in most countries around Europe. ${ }^{24}$ They are well placed to provide diagnosis and management of mild and most of the moderate allergic conditions as well as to refer individuals with complex and severe allergies to specialist services. ${ }^{24}$ Many publications have identified that the training offered to PCPs in allergy currently is inadequate. $^{18-23} 4749$ The current inadequacies in training and the need for more information and training for PCPs in allergy were reinforced in studies reported from Scotland, Italy and Spain. ${ }^{7}$

It was argued in the two European publications that a model of care which is centred on specialists or consultants is untenable in allergy. ${ }^{724}$ In public-funded health systems such as the UK where PCPs assess and manage the majority of patients, the burden placed by allergy and related conditions on primary care could be significant. For example, it was estimated that allergy accounts for $8 \%$ of all general practice consultations in the UK and that up to $11 \%$ of the total drugs budget is spent on allergy-related medication (including asthma and eczema). ${ }^{18}$

One particular article mentioned the lack of access to secondary services as allergy's 'greatest unmet need'. Referral times to specialists vary considerably across Europe from over 3 months in some tax-funded health systems ${ }^{7202240}$ to as little as 1 week when specialists can be accessed privately. ${ }^{7}$ Across Europe organ specialists are generally more readily accessible to PCPs than allergists. $^{7}$ In a UK-based survey of over 480 PCPs, $81.5 \%$ of the 240 PCPs who responded felt that the NHS allergy services were poor and $80 \%$ felt that secondary care provision was inadequate. ${ }^{49}$ These practitioners admitted to being especially anxious about treating children with food allergies, although most felt quite confident about managing common allergic conditions such as anaphylaxis, urticaria, allergic rhinitis and drug allergy. ${ }^{49}$

\section{PCPs with an interest in allergy}

Two publications specifically discussed a second tier service for allergy within primary care. ${ }^{7}{ }^{53}$ Such an arrangement was also proposed by the House of Lords report. ${ }^{18}$ In the UK, a prospective evaluation of patients referred to a General Practitioner with Special Interest $(\mathrm{GPwSI})$ in allergy revealed that the services were well received, reduced the levels of secondary care referral and had a potential for cost savings. ${ }^{43}$ Further, PCPs in this study referred patients more readily to the GPwSI than to secondary care. ${ }^{43}$ However, establishing these services would need a well-defined process of accreditation and specialist mentorship ${ }^{24}$ which may be difficult to achieve in most countries given the current severe shortage in the availability of specialists across Europe. $^{3} 24$

\section{Non-physician services in primary care}

Non-physician services for allergy were specifically discussed by six publications in this review. ${ }^{18} 2022444751$ Most of the articles discuss the underusage of these professionals in allergy and suggest that there is a scope for better training of nurses, pharmacists and dieticians in allergy. Depending on the extent of training and the competencies achieved, nurses could be involved with testing, diagnosis and management of patients with allergy. ${ }^{47}$

Some authors felt that pharmacists could, if adequately trained and sufficiently supervised, provide information to patients regarding techniques for using devices such as nasal sprays, eye drops, epinephrine auto-injectors as well as inhalers for allergy and related conditions. ${ }^{18}{ }^{47}$ They could help patients choose over the counter medication for allergy judiciously. They can also be trained to advice individuals on the need for consultation with their PCP, where appropriate. ${ }^{22}$ The House of Lords committee suggested that pharmacists should be formally trained in allergy to ensure that good quality advice on allergy medication can be provided to all patients. ${ }^{18}$ This committee also reported concerns from clinicians regarding availability of unvalidated tests over the counter for allergies in some establishments. ${ }^{18}$ There are, however, no publications to-date formally assessing the role of pharmacists in the diagnosis and management of allergy.

\section{Barriers to providing optimal allergy care in the primary care sector}

Several authors were concerned that PCPs do not receive structured instruction in allergy during their training, and very few are familiar with guidelines for the management of allergic disease. ${ }^{7}$ 20-22 33 The House of Commons health committee highlighted the lack of allergy knowledge in primary care as "...one of the 
principal causes of distress to patients" ${ }^{19}$ Some articles have specifically highlighted the significant gaps in allergy training at the undergraduate and postgraduate levels, as well as inadequate continuing medical education programmes for PCPs in allergy. ${ }^{20} 2124$ This was identified as leading to inappropriate referrals to a range of specialists, ${ }^{23}$ lack of engagement with secondary care services for allergy, delays in diagnosis and starting appropriate management ${ }^{20}$ and, sometimes, to inappropriate management. ${ }^{33}$ All these issues resulted in poor patient experience and also cause a significant wastage of scarce healthcare resources. ${ }^{20}{ }^{21} \mathrm{~A}$ retrospective review of the patients at a secondary care allergy clinic in Sussex showed that at least $42 \%$ of patients were referred for conditions that could have easily been managed in primary care, had the PCPs been appropriately trained. ${ }^{36}$ An Irish study also suggested that increasing awareness of common allergic conditions among PCPs can significantly reduce referrals to specialists. ${ }^{54}$ This suggestion was reinforced in UK government reports ${ }^{19-22}$ and other studies. $^{23}$

In most countries, the lack of leadership and support offered by a stable, well-staffed specialist service was identified as one of the main barriers to improvement of primary care services. ${ }^{7} 18-21$

\section{Secondary care services \\ Availability of specialist services}

A publication by the World Allergy Organisation (WAO) has suggested that there is a great degree of heterogeneity in access to specialist allergy services across the world. $^{3}{ }^{40}$ Experts point out that while there has been very little increase in availability over the last few years, the demand for specialist allergy services has been steadily increasing. ${ }^{21}$ For example, the number of certified allergy specialists per head of population range from 1:25 million (in Malaysia) to about 1:2 million (in the UK) and 1:16 000 (in Germany). ${ }^{3}$

Heterogeneity in specialist training has also been highlighted $^{333}$ with only a few countries providing certified courses to practitioners in allergy. A worldwide study by the WAO showed that paediatric allergy services are particularly underserved and children with allergic problems are often managed by general paediatricians with or without formal allergy training. ${ }^{3}$ This study also found that in many countries children may be managed by specialist adult physicians without appropriate paediatric training. ${ }^{3}$ Specialist training pathways for allergy vary markedly worldwide. In countries such as the UK, formal certification procedures in either allergy alone or in a combination of allergy and immunology exist. Similarly, in the USA, allergists/immunologists should have passed a professional examination taken after 2 years of structured specialty training. In other countries, allergy may be included as a subspecialty in general internal medicine or paediatrics training. ${ }^{3}$ In Germany, for example, allergology is considered a subspecialty of dermatology. ${ }^{18}$ In the UK, the British Society for Allergy and Clinical
Immunology (BSACI) has estimated that $90 \%$ of secondary care in the UK is provided by allergists and immunologists. ${ }^{45}$ A study carried out in the UK has shown that immunologists, who have formal training in allergy, provide allergy care to 32 million individuals in the UK. ${ }^{46}$ Some authors have pointed out that immunologists are indeed the sole providers of allergy services in parts of the UK. ${ }^{44}{ }^{46}$ Other specialists such as those with primary qualifications in ENT, respiratory medicine or dermatology also contribute to the delivery of allergy services in many countries ${ }^{3}$ including about $10 \%$ of the total secondary care for allergy in the UK. ${ }^{45}$ Even if this broad definition of allergy specialists were to be accepted, many experts feel that allergy services remain inadequate in most countries in the face of increasing demand for these services. $^{3} 1940$

\section{Specialist centres for allergy}

Some authors propose the 'hub and spoke' model ${ }^{18-20} 40$ which involves the establishment of supraregional tertiary allergy centres (or Hubs) which can support regional secondary and primary care centres (the so-called spokes) for delivery of specialist services. A few suggested that these centres should be manned by consultant adult and paediatric allergists, nurse specialists as well as adult and paediatric dieticians while providing facilities for training at least two specialist registrars in allergy. ${ }^{20}$ Others felt that these should be multispecialist centres (eg, chest physician, dermatologist, ENT specialist, paediatrician in addition to an allergist or clinical immunologist) that are built on existing expertise of the local area and serve as 'clusters of expertise'. ${ }^{18}$ In some countries, these centres would typically be university hospitals which would receive referrals only from specialists. ${ }^{18}$

Whatever their composition, most agreed that these centres could serve to educate and support primary and secondary care physicians in the region. ${ }^{18-20}$ It was suggested that they had a potential to serve as centres of excellence for adults and children with complex and severe allergies; establish a good, working network between organ-based specialists, generalists and allergists and serve to improve the overall provision of allergy services in the region. ${ }^{18}$

Some experts point out that the existing shortage of specialists in allergy would be a barrier to the development of such centres. ${ }^{21} 50$ A pilot study carried out in the North West region of England found that developing large tertiary centres would not be practical in regions with large cities in close proximity to one another. ${ }^{23}$ They may not be cost-effective for many regions within the $\mathrm{UK}^{21}$ and perhaps, Europe.

The House of Commons health committee has pointed out that there are no clear data to suggest that specialist centres improve clinical outcomes in allergy management. ${ }^{19}{ }^{41}$ Indeed, even in countries like Germany with a relatively high proportion of allergy specialists per 100000 population, the numbers of emergency admissions for allergy remain high. ${ }^{3}$ The North 
East England pilot study found that the lack of confidence among general practitioners while dealing with patients with allergy led to poor referral practices. ${ }^{23}$ As a consequence, management of simple conditions took up a disproportionate amount of specialist time and resources while individuals with complex allergies faced long waiting lists as well as inappropriate referrals to other specialists. $^{23}$

\section{Future direction for services}

While efforts are being made to improve allergy education at the undergraduate and postgraduate levels, there has been a focus also on the improvement of training of current practitioners. The Royal College of Paediatrics and Child health has developed care pathways for children which define core competencies for all those involved in managing these conditions and are freely accessible online. ${ }^{42}$ These are UK based but potentially can be modified to suit other countries. Such pathways embrace the current heterogeneity in service delivery while attempting to raise standards.

The 'Hub and spokes' model was trialled in the UK with mixed results, which was specifically discussed in a report. ${ }^{23}$ The authors suggested that new services should be tagged onto existing pathways and also stated that a care model of visiting specialists in secondary centres would be more welcome in some areas than the establishment of large tertiary centres. ${ }^{23}$ It was also suggested that models of good care can vary from one region to another. ${ }^{21} 23$

There have been recent publications regarding the use of digital technology in the provision of allergy services. ${ }^{37-39}$ One addresses the use of telemedicine in improving communications between primary and secondary care in order to improve adult allergy pathways within the NHS; ${ }^{37}$ whereas another makes a case for clinical trials using information communication and technology (ICT) in management of allergic rhinitis in Europe. ${ }^{38}$ A publication from Ireland reported on the use of an email communication system, which received an average of only four enquiries per month over a 12 -month period. Although it was rated useful by $100 \%$ of the responding non-specialists (response rate of $35 \%$ ), this communication system did not reduce referrals to the specialist allergy services. ${ }^{39}$

There has been a lot of interest lately in the 'Finnish model' of service reorganisation. This re-structuring exercise takes inspiration from the successful interventions for asthma in Finland. ${ }^{32}$ While acknowledging the differences between asthma and allergy and emphasising the need to understand and improve tolerance to allergens, the architects of this model hope to use the existing asthma infrastructure to improve services for allergy sufferers. They suggest that increased initial outlay aimed at preventing allergies and changing attitudes towards health alongside improving service delivery can reduce the cost and burden of allergic disease in the future. ${ }^{32}$ The results of this experiment are currently awaited.

\section{DISCUSSION}

\section{Principal findings of the review}

This systematic review aimed to identify and discuss various pathways that are relevant to the delivery of allergy services. There were large gaps in the literature pertaining to services in countries with high rates of allergy (such as Australia, New Zealand, USA) ${ }^{15}$ as well as very populous regions of the world including China, India, Brazil and the whole of Africa. In addition, there was a lack of well-designed studies in this area with only three prospective studies identified. ${ }^{23} 3243$ None of the studies included a control group. Two of these publications $^{23} 32$ describe service reorganisation on a large scale with direct involvement of the relevant health ministries.

There is clear evidence from the literature that allergy services across the world have not kept up with rising demand. The 'allergy epidemic' ${ }^{13}$ has surprised unprepared health systems globally. There has been failure on the part of governments and fund holders to acknowledge the rapid rise in allergies. Given that there are no signs of abatement in the observed increase in allergies worldwide,${ }^{2}$ it is conceivable that the demand on services is set to increase even higher over the next few years. The psychosocial impact of these conditions is often overlooked. For example, atopic individuals experience significantly worse memory and cognitive ability during allergy season. ${ }^{55}$ Children with eczema report higher levels of anxiety and depression. ${ }^{56}$ In addition, these conditions currently place an inordinate financial burden on healthcare services. ${ }^{29} 5758$ Urgent and effective measures are therefore needed to cope with the problem.

About three-quarters of the eligible publications in this review $(18 / 23)$ are from the UK which suggests that there has been a lot of interest here in investigating the extent of the supply gap in allergy services over the last 15 years. It is striking however, that while most of these reports describe the problems with service delivery and suggest some solutions, none seem to have addressed the problem in a structured manner. There has been no response to the UK Department of Health's request for reliable baseline data on needs of the population; costs involved in service reorganisation; and the skills and competencies of the existing workforce in order that future services can be planned. ${ }^{445} 48$

Primary care services are key to optimal management of allergy. Appropriate management after good history taking and specific testing can easily be achieved in primary care for a majority of patients. Referral to specialist centres can be limited to only complex patients needing multidisciplinary input or those that need desensitisation therapy. However, a UK survey has shown that PCP confidence in managing allergies in children ${ }^{49}$ and initiating referrals appropriately is limited. While PCPs in this particular survey felt confident about managing adults, studies have shown that most individuals referred to secondary care could have been managed effectively in primary care. ${ }^{23} 5459$ This serves to highlight the inadequate training received by PCPs in allergy 
at undergraduate and postgraduate levels. This leads to not only poor patient experience and outcomes but is also more expensive to the health service providers.

Owing to lack of specialists in allergy, patients are often referred to specialists who can, perhaps, only deal with individual manifestations of allergy (eg, respiratory physicians for allergic asthma; ophthalmologists for allergic eye disease). Organ-based specialists play a very important role in the management of allergic disease. Indeed, in some instances (eg, children with very severe disease), their input is essential. However, specialists in allergy can provide clinically effective and potentially cost-effective services by intervening across several of these conditions for most patients. ${ }^{20}$

Scarcity and inequity of specialist allergy services is a recurring theme in many articles worldwide. Although numerous publications have made a compelling case for more specialist centres, ${ }^{3}$ 18-21 33 these have not been forthcoming. Many factors appear to contribute to this apparent inertia, ${ }^{21}$ the important ones being lack of adequate central funding to increase training numbers for specialists, lack of interest in allergy services among fund holders, ${ }^{23}$ lack of clarity regarding the role of various specialists involved. ${ }^{21}$ Another important issue is the lack of formal training programmes in allergy in many countries. ${ }^{3}$ This not only blights the care of individuals with allergy in these countries, but also prevents the specialty being taken seriously by decision makers. In the case of the UK, lack of clinical codes to measure allergy activity and disagreements between the two main specialist groups that provide allergy services (allergists and immunologists) are also important issues. ${ }^{48}$ Further, in the UK, the lack of specialist services and poor referral practices within primary care have resulted in unreliable waiting list data, which are often used as a surrogate marker for need within the NHS. ${ }^{44}$ This has proved to be a barrier for further investment in services. ${ }^{48}$

It should be noted that there are no published data that support the success of large, tertiary centres. Nevertheless, it is conceivable that centres which treat large volumes of individuals will provide better outcomes for complicated patients. ${ }^{60}$ However, the lack of confidence among general practitioners while dealing with patients with allergy leads to poor referral practices leading to long waiting lists as well as inappropriate referrals to other specialists. ${ }^{23}$

There have been many encouraging advances in allergy service reorganisation in the UK and beyond. New multiconsultant allergy centres were created in the North West of England as per the recommendations of the House of Lords report into allergy services. ${ }^{18}$ This service development encountered many barriers including non-engagement of local commissioners, nonavailability of appropriately trained staff and poor coding practices. ${ }^{23}$ Nevertheless, the project was successful in improving networking among specialists across the region, improved clinical governance including audit, better regional education programmes for clinical staff and patients in allergy. ${ }^{23}$ There was an opportunity during the course of this project to prospectively collect data on patient experiences and outcomes, which was unfortunately missed.

The heterogeneity in specialist training across Europe is also being addressed with the introduction of the European Examination in Allergology and Clinical Immunology since 2008 by the European Academy of Allergy and Clinical Immunology (EAACI). The aim of this examination is to "raise standard of allergology and clinical immunology in Europe" and to "facilitate the exchange of young people trained in Allergology and Clinical Immunology" in Europe. ${ }^{61}$

The Finnish allergy model is based on the very successful restructuring of asthma care in Finland ${ }^{62}$ and is now being adapted to the management of other chronic conditions. ${ }^{63}$ In Finland, the model has been altered to incorporate the complex and heterogeneous nature of allergy but it essentially builds on the existing infrastructure developed for the asthma programme. ${ }^{32}$ The Finnish allergy plan is an ambitious project that aims to reduce the burden of allergic disease by improving tolerance and reducing the emphasis on allergen avoidance in affected individuals. The objective is to help alleviate the psychosocial aspects of allergy while improving services provided to these persons. ${ }^{32}$ Aspects of this plan have also been adopted by Norway ${ }^{64}$ and by a health authority in North West London as well as in Sheffield. ${ }^{65}$ Preliminary results from the London project are very encouraging. ${ }^{3166} 67$ More data are awaited to ascertain whether the project has been successful and also if this success can be emulated in other regions.

\section{Strengths and limitations of the review}

The strength of this review is that it provides a systematic and comprehensive look at the reported current provision of allergy services across the world. There are some limitations to this review, mainly due to paucity of information from most countries, including some with relatively high allergy incidence and prevalence, regarding available services. Most of the literature is UK based and hence generalisability of data to other countries, especially those without publicly funded health systems may be limited. In addition, there were very few well-planned prospective studies and no controlled studies in this area. Most of the included studies had little empirical data, and therefore a formal quality assessment of the publications was not carried out. Studies not reported in the English language were excluded.

\section{Strengths and limitations in relation to other studies}

This paper is the first to comprehensively review all the published reports and journal articles on allergy services. Our review, in concurrence with a previous UK review, ${ }^{45}$ found that prospective studies in the area were lacking and that there were no data objectively comparing different levels of service delivery (eg, primary care vs secondary care). 


\section{CONCLUSIONS}

There is a consensus that allergy services across the world are inadequate to meet the rising demand. There is a high degree of heterogeneity and inequity in the availability of services across the world. Untreated or poorly treated allergic conditions can have a high psychosocial impact on individuals and can place a substantial economic burden on healthcare services. Allergy training is not adequately provided in the current undergraduate and postgraduate medical curricula, which is adversely affecting patient care at all levels, especially in primary care. Primary care services are affected by poor training of practitioners and by poor access to specialists. Specialist services are hampered by the non-availability of appropriately trained personnel and poor referral practices from primary care (where applicable) which lead to long waiting lists and poor overall patient care. There is currently no clear consensus on how services should be structured although the Finnish model of service reorganisation has shown significant promise. Political engagement and patient empowerment are important to the success of these projects.

\section{Future research}

There is a need for data on service pathways from across the world, especially from countries with a high burden of allergic disease so that the extent of the problem can be identified and lessons may be learnt from successful models. Prospective data aimed at estimating the costs and outcomes of service pathways are especially important. To ensure that a service is successfully re-organised, it is important to understand the needs of the local population, their preferences for services and to estimate costs and benefits of the possible service pathways. This literature review forms part of a wider project which aims to achieve these objectives for the population of the West Midlands region of the UK.

\section{Twitter Follow Tracy Roberts @tracyrobertsbham}

Contributors All the authors contributed significantly to the planning, execution of this review and to the preparation of the manuscript. LD carried out the systematic review and wrote the manuscript. CC, RL and TR regularly reviewed the work and provided advice.

Funding This work was supported by the Wellcome Trust, grant number $100064 / Z / 12 / Z$ (DD). CC is part supported by the National Institute for Health Research (NIHR) Collaboration for Leadership in Applied Health Research and Care West Midlands.

Disclaimer This paper presents independent research and the views expressed are those of the authors and not necessarily those of the NHS, the NIHR or the Department of Health.

Competing interests None declared.

Provenance and peer review Not commissioned; externally peer reviewed.

Data sharing statement No additional data are available.

Open Access This is an Open Access article distributed in accordance with the terms of the Creative Commons Attribution (CC BY 4.0) license, which permits others to distribute, remix, adapt and build upon this work, for commercial use, provided the original work is properly cited. See: http:// creativecommons.org/licenses/by/4.0/

\section{REFERENCES}

1. Beasley R. Worldwide variation in prevalence of symptoms of asthma, allergic rhinoconjunctivitis, and atopic eczema: ISAAC Lancet 1998;351:1225-32.

2. Butland BK, Strachan DP, Lewis S, et al. Investigation into the increase in hay fever and eczema at age 16 observed between the 1958 and 1970 British birth cohorts. BMJ 1997;315:717-21.

3. Warner JO, Kaliner MA, Crisci CD, et al. Allergy practice worldwide -a report by the World Allergy Organization Specialty and Training Council. Allergy Clin Immunol Int 2006;18:4-10.

4. Weinmayr G, Forastiere F, Weiland SK, et al. International variation in prevalence of rhinitis and its relationship with sensitisation to perennial and seasonal allergens. Eur Respir J 2008;32:1250-61.

5. Aït-Khaled N, Pearce N, Anderson HR, et al. Global map of the prevalence of symptoms of rhinoconjunctivitis in children: The International Study of Asthma and Allergies in Childhood (ISAAC) Phase Three. Allergy 2009;64:123-48.

6. Osborne NJ, Koplin JJ, Martin PE, et al. Prevalence of challenge-proven IgE-mediated food allergy using population-based sampling and predetermined challenge criteria in infants. J Allergy Clin Immunol 2011;127:668-76.e2.

7. Agache I, Ryan D, Rodriguez MR, et al. Allergy management in primary care across European countries-actual status. Allergy 2013;68:836-43.

8. Morawetz DY, Hiscock H, Allen KJ, et al. Management of food allergy: a survey of Australian paediatricians. J Paediatr Child Health 2014;50:432-7.

9. Gibbison B, Sheikh A, McShane P, et al. Anaphylaxis admissions to UK critical care units between 2005 and 2009. Anaesthesia 2012;67:833-8.

10. Rudders SA, Banerii A, Vassallo MF, et al. Trends in pediatric emergency department visits for food-induced anaphylaxis. J Allergy Clin Immunol 2010;126:385-8.

11. Lin RY, Anderson AS, Shah SN, et al. Increasing anaphylaxis hospitalizations in the first 2 decades of life: New York State, 19902006. Ann Allergy Asthma Immunol 2008;101:387-93.

12. Poulos LM, Waters AM, Correll PK, et al. Trends in hospitalizations for anaphylaxis, angioedema, and urticaria in Australia, 1993-1994 to 2004-2005. J Allergy Clin Immunol 2007;120:878-84.

13. Holgate ST. The epidemic of allergy and asthma. Nature 1999:402:2-4.

14. Anandan C, Gupta R, Simpson CR, et al. Epidemiology and disease burden from allergic disease in Scotland: analyses of national databases. J $R$ Soc Med 2009;102:431-42.

15. Punekar YS, Sheikh A. Establishing the sequential progression of multiple allergic diagnoses in a UK birth cohort using the General Practice Research Database. Clin Exp Allergy 2009;39:1889-95.

16. Ninan TK, Russell G. Respiratory symptoms and atopy in Aberdeen schoolchildren: evidence from two surveys 25 years apart. BMJ 1992;304:873-5.

17. Gupta R, Sheikh A, Strachan DP, et al. Time trends in allergic disorders in the UK. Thorax 2007;62:91-6.

18. House of Lords. Science and Technology Committee: Sixth report: allergy. London: House of Lords, 2007.

19. House of Commons Health Committee. The provision of allergy services: sixth report of Session 2003-04: Volume II: Oral and written evidence. House of Commons, 2004

20. The Royal College of Physicians Working Party. Allergy : the unmet need. A blueprint for better patient care. London, UK: The Royal College of Physicians, 2003.

21. The Royal College of Physicians and Royal College of Pathologists Working Party. Allergy services: still not meeting the unmet need. London, UK: The Royal College of Physicians and Royal College of Pathologists, 2010.

22. Scottish Medical and Scientific Advisory Committee. Immunology and allergy services in Scotland. The Scottish Government, 2009.

23. Sinnott L, Dudley-Southern R. Developing allergy services in the North West of England: lessons learnt. North West NHS Specialised Commissioning Group, 2011.

24. Jutel M, Angier L, Palkonen S, et al. Improving allergy management in the primary care network - a holistic approach. Allergy 2013;68:1362-9.

25. Cummings AJ, Knibb RC, King RM, et al. The psychosocial impact of food allergy and food hypersensitivity in children, adolescents and their families: a review. Allergy 2010;65:933-45.

26. Akeson N, Worth A, Sheikh A. The psychosocial impact of anaphylaxis on young people and their parents. Clin Exp Allergy 2007;37: 1213-20.

27. Gupta R, Sheikh A, Strachan DP, et al. Burden of allergic disease in the UK: secondary analyses of national databases. Clin Exp Allergy 2004;34:520-6. 
28. Lamb CE, Ratner PH, Johnson CE, et al. Economic impact of workplace productivity losses due to allergic rhinitis compared with select medical conditions in the United States from an employer perspective. Curr Med Res Opin 2006;22:1203-10.

29. Zuberbier T, Lötvall J, Simoens S, et al. Economic burden of inadequate management of allergic diseases in the European Union: a GA2LEN review. Allergy 2014;69:1275-9.

30. Hankin CS, Cox L, Bronstone A, et al. Allergy immunotherapy: reduced health care costs in adults and children with allergic rhinitis. J Allergy Clin Immunol 2013;131:1084-91.

31. Griffin R, Gore C, Aston A, Hall S, Warner J, eds. Results of a 12 month children's integrated community allergy pathway project, 'Itchy-Sneezy-Wheezy'. Clinical and experimental allergy. Hoboken (NJ): Wiley-Blackwell, 2015.

32. Haahtela $\mathrm{T}$, von Hertzen L, Makela M, et al. Finnish Allergy Programme 2008-2018-time to act and change the course. Allergy 2008;63:634-45.

33. Ewan P, Durham SR. NHS allergy services in the UK: proposals to improve allergy care. Clin Med 2002;2:122-7.

34. Peters MD, Godfrey CM, Khalil $\mathrm{H}$, et al. Guidance for conducting systematic scoping reviews. Int J Evid Based Healthc 2015;13:141-6.

35. Liberati A, Altman DG, Tetzlaff J, et al. The PRISMA statement for reporting systematic reviews and meta-analyses of studies that evaluate health care interventions: explanation and elaboration. PLoS Med 2009;6:e1000100.

36. Isinkaye $\mathrm{T}$, Gilbert $\mathrm{S}$, Seddon $\mathrm{P}$, et al. How many paediatric referrals to an allergist could be managed by a general practitioner with special interest? Pediatr Allergy Immunol 2016;27:195-200.

37. Krishna MT, Knibb RC, Huissoon AP. Is there a role for telemedicine in adult allergy services? Clin Exp Allergy 2016;46:668-77.

38. Bousquet J, Schunemann HJ, Fonseca J, et al. MACVIA-ARIA Sentinel Network for allergic rhinitis (MASK-rhinitis): the new generation guideline implementation. Allergy 2015;70:1372-92.

39. Conlon NP, Abramovitch A, Murray G, et al. Allergy in Irish adults: a survey of referrals and outcomes at a major centre. Ir J Med Sci 2015;184:349-52.

40. Chan YT, Ho HK, Lai CK, et al. Allergy in Hong Kong: an unmet need in service provision and training. Hong Kong Med J 2015;21:52-60.

41. Jones R, O'Connor A, Kaminski E. Patients' experience of a regional allergy service. J Public Health Res 2013;2:e13.

42. Warner JO, Lloyd K. Shared learning for chronic conditions: a methodology for developing the Royal College of Paediatrics and Child Health (RCPCH) care pathways for children with allergies. Arch Dis Child 2011;96(Suppl 2):i1-5.

43. Levy ML, Walker S, Woods A, et al. Service evaluation of a UK primary care-based allergy clinic: quality improvement report. Prim Care Respir J 2009:18:313-9.

44. Department of Health. Government response to House of Lords Science and Technology Committee report on Allergy: sixth report of session 2006-07. London, UK: Department of Health, 2007.

45. Department of Health Allergy Services Review Team. A review of services for allergy - the epidemiology, demand for and provision of treatment and effectiveness of clinical interventions. London: Department of Health, 2006.

46. El-Shanawany TM, Arnold H, Carne E, et al. Survey of clinical allergy services provided by clinical immunologists in the UK. J Clin Pathol 2005;58:1283-9.

47. Ryan D, Levy M, Morris A, et al. Management of allergic problems in primary care: time for a rethink? Prim Care Respir J 2005;14:195-203.
48. Department of Health. Government response to the House of Commons Health Committee report on the Provision of Allergy Services: Sixth report of session 2003-04. Report. London, UK: Department of Health, 2005.

49. Levy ML, Price D, Zheng X, et al. Inadequacies in UK primary care allergy services: national survey of current provisions and perceptions of need. Clin Exp Allergy 2004;34:518-9.

50. Ewan PW. Provision of allergy care for optimal outcome in the UK. Br Med Bull 2000;56:1087-101.

51. Brydon M. The effectiveness of a peripatetic allergy nurse practitioner service in managing atopic allergy in general practice-a pilot study. Clin Exp Allergy 1993;23:1037-44.

52. Haahtela T. A national allergy program 2008-2018. Drugs Today 2008;44(Suppl B):89-90.

53. Levy ML, Sheikh A, Walker $\mathrm{S}$, et al. Should UK allergy services focus on primary care? BMJ 2006;332:1347-8.

54. Conlon NP, Edgar JDM. Adherence to best practice guidelines in chronic spontaneous urticaria (CSU) improves patient outcome. Eur J Dermatol 2014;24:385-6.

55. Blaiss MS. Cognitive, social, and economic costs of allergic rhinitis. Allergy Asthma Proc 2000;21:7-13.

56. Hon KL, Pong NH, Poon TCW, et al. Quality of life and psychosocial issues are important outcome measures in eczema treatment. J Dermatolog Treat 2015;26:83-9.

57. Fox M, Mugford M, Voordouw J, et al. Health sector costs of self-reported food allergy in Europe: a patient-based cost of illness study. Eur J Public Health 2013;23:757-62.

58. Gupta R, Holdford D, Bilaver L, et al. The economic impact of childhood food allergy in the United States. JAMA Pediatr 2013;167:1026-31.

59. Jones RB, Hewson $\mathrm{P}$, Kaminski ER. Referrals to a regional allergy clinic-an eleven year audit. BMC Public Health 2010;10:790.

60. O'Neill M, Karelas GD, Feller DJ, et al. The HIV workforce in New York State: does patient volume correlate with quality? Clin Infect Dis 2015;61:1871-7.

61. European Academy of Allergy and Clinical Immunology. EAACI knowledge exam 2016 (cited 11 October 2016). http://www.eaaci. org/activities/eaaci-exam/upcoming-exam.html

62. Haahtela T, Tuomisto LE, Pietinalho A, et al. A 10 year asthma programme in Finland: major change for the better. Thorax 2006;61:663-70.

63. Kinnula VL, Vasankari T, Kontula E, et al. The 10-year COPD programme in Finland: effects on quality of diagnosis, smoking prevalence, hospital admissions and mortality. Prim Care Respir $J$ 2011;20:178-83.

64. Lodrup Carlsen KC, Haahtela T, Carlsen KH, et al. Integrated allergy and asthma prevention and care: report of the MeDALL/AIRWAYS ICPs meeting at the ministry of health and care services, Oslo, Norway. Int Arch Allergy Immunol 2015;167:57-64.

65. Sheffield Childrens NHS Foundation Trust. Itchy, Sneezy, Wheezy clinic to combat allergies 2014 [9 November 2015]. http://www. sheffieldchildrens.nhs.uk/news/itchy-sneezy-wheezy-clinicto-combat-allergies.htm

66. Taha S, Patel N, Gore C. G388 'Itchy-Sneezy-Wheezy' survey: comparison of GP referral reasons to diagnoses on first allergy clinic letters. Arch Dis Child 2014;99(Suppl 1):A161-A.

67. Patel N, Warner J, Gore C, eds. Itchy 'sneezy' wheezy survey: how do referral reasons to allergy clinic compare to diagnoses made at first allergy clinic visit? Clinical and experimental allergy. Hoboken (NJ): Wiley-Blackwell, 2012. 